\title{
Changes in Freezing Point of Blood and Milk During Dehydration and Rehydration in Lactating Cows
}

\author{
M. Bjerg, ${ }^{1}$ M. D. Rasmussen, ${ }^{1}$ and M. O. Nielsen ${ }^{2}$ \\ ${ }^{1}$ Department of Animal Health, Welfare and Nutrition, Danish Institute of Agricultural Sciences, \\ Research Centre Foulum, DK-8830 Tjele, Denmark \\ ${ }^{2}$ Department of Basic Animal and Veterinary Sciences, The Royal Veterinary and Agricultural University, \\ DK-1870 Frederiksberg C, Denmark
}

\begin{abstract}
We studied the influence of short-term changes in water intake in 4 lactating Holstein cows on diurnal fluctuation of packed cell volume (PCV), freezing point of blood $\left(\mathrm{FP}_{\text {blood }}\right)$, freezing point of milk $\left(\mathrm{FP}_{\text {milk }}\right)$, and the relationship between changes in $\mathrm{FP}_{\text {blood }}$ and $\mathrm{FP}_{\text {milk }}$. The experiment lasted $108 \mathrm{~h}$ and was divided into 3 periods: 1) control (38 h); 2) dehydration/rehydration with 4 consecutive 12 -h sequences: $8 \mathrm{~h}$ without water, 0.5 - $\mathrm{h}$ access to water, $1.5 \mathrm{~h}$ without water, and 2 -h access to water; and (3) $22 \mathrm{~h}$ for reconstitution. Cows were milked at 12 -h intervals. Blood was sampled from the jugular vein hourly throughout the experiment, and at $0,15,30,60,90,120,150,180,210$, and $240 \mathrm{~min}$ after initiated rehydration following the 8-h dehydration sequences. Intakes of free water and water in feed were recorded every hour. The PCV was negatively affected by water intake within the hour before sampling. Dehydration lowered $\mathrm{FP}_{\text {blood }}$ steadily, whereas $\mathrm{FP}_{\text {blood }}$ increased by $0.024^{\circ} \mathrm{C}$ within 30 min following a large water intake in the rehydration period. The $\mathrm{FP}_{\text {blood }}$ was not significantly influenced by actual water intake, but was highly correlated with the available water pool at time of blood sampling. The $\mathrm{FP}_{\text {milk }}$ correlated positively with the $\mathrm{FP}_{\text {blood }}$ collected $1 \mathrm{~h}$ before milk sampling, indicating a delay in the transfer of water from plasma to milk. In summary, $\mathrm{FP}_{\text {blood }}$ and $\mathrm{FP}_{\text {milk }}$ decrease during dehydration and increase during rehydration. Rehydration following a long dehydration period caused an increase in $\mathrm{FP}_{\text {milk }}$ within $1 \mathrm{~h}$, but not above the initial level for $\mathrm{FP}_{\text {milk }}$ of the cow.
\end{abstract}

(Key words: freezing point, blood, milk, packed cell volume)

Abbreviation key: AWI = actual water intake, AWP = available water pool, DE- = dehydration sequence, $\mathbf{F P}_{\text {blood }}=$ freezing point of blood, $\mathbf{F P}_{\text {milk }}=$ freezing point

Received December 23, 2004.

Accepted May 26, 2005.

Corresponding author: Morten Dam Rasmussen; e-mail: MortenD.Rasmussen@agrsci.dk. of milk, $\mathbf{P C V}=$ packed cell volume, $\mathbf{R E}-=$ rehydration sequence.

\section{INTRODUCTION}

The freezing point of bulk tank milk varies throughout the year, and Danish data show that the value is highest in summer (July) and lowest in early winter (November). Increasing ambient temperature and number of sunshine hours is known to raise the freezing point of milk $\left(\mathbf{F P} \mathbf{P}_{\text {milk }}\right)$, and it is therefore likely that the increased freezing point of bulk tank milk during the summer period is caused by increased water intake (Bjerg and Rasmussen, 2005). Modern dairy cows have large water requirements, especially during a hot summer day, and it is of interest to know if diurnal variations between dehydration and rehydration influence the $\mathrm{FP}_{\text {milk. }}$.

The $\mathrm{FP}_{\text {milk }}$ is determined by the osmolality of the milk; that is, the concentration of water-soluble constituents. The sum of lactose, chloride, citrate, and lactic acid accounts for 79 to $86 \%$ of the total $\mathrm{FP}_{\text {milk }}$ (Mitchell, 1989), with lactose and chloride accounting for about 55 and 25\%, respectively (Wheelock et al., 1965). The remaining attributions come from other soluble constituents such as sodium, calcium, potassium, magnesium, phosphate, casein, and urea (Wheelock et al., 1965).

A high correlation was found between the $\mathrm{FP}_{\text {milk }}$ and that of mammary venous blood (Wheelock et al., 1965; Green et al., 1969; Tucker, 1970). During water deprivation in camels (Dahlborn et al., 1997) and goats (Dahlborn, 1987), plasma osmolality and milk osmolality have been reported to increase simultaneously, and similarly plasma osmolality and milk osmolality will decrease in response to rehydration (Dahlborn et al., 1997). However, Little et al. (1984) reported that osmolality does not increase until $24 \mathrm{~h}$ after initiated water deprivation, and this corresponds with other findings where transfer time of ${ }^{3} \mathrm{H}_{2} \mathrm{O}$ has been studied from plasma to milk and from rumen to plasma. Linzell and Peaker (1971b) reported a lag phase of approximately 25 min after an i.v. infusion of ${ }^{3} \mathrm{H}_{2} \mathrm{O}$ before milk in the 
alveoli was fully equilibrated with plasma with respect to ${ }^{3} \mathrm{H}_{2} \mathrm{O}$.

After infusion of ${ }^{3} \mathrm{H}_{2} \mathrm{O}$ into the rumen of hydrated lactating ewes (Benlamlih and Oukessou, 1990), 24-h dehydrated goats (Holtenius, 1986), or 48-h dehydrated sheep (Dahlborn and Holtenius, 1990), approximately $70 \%$ of the ${ }^{3} \mathrm{H}_{2} \mathrm{O}$ activity (expressed as percentage of the equilibration value) could be measured in plasma within the first hour after infusion. After $4 \mathrm{~h}$, the equilibration is nearly completed (Benlamlih and Oukessou, 1990; Dahlborn and Holtenius, 1990). Wheelock et al. (1965) demonstrated that the freezing point of blood $\left(\mathbf{F P}_{\text {blood }}\right)$ and $\mathrm{FP}_{\text {milk }}$ increased steadily over $2.5 \mathrm{~h}$ when a 24-h-water-restricted Friesian cow (20 to $25 \mathrm{~kg}$ of milk/d) had a sudden intake of $50 \mathrm{~kg}$ of water. Subsequently, the values plateaued for about $5 \mathrm{~h}$ and then decreased progressively to the original values after a further $16.5 \mathrm{~h}$. It is likely that the increased water need in high-yielding cows affects the diurnal variation in $\mathrm{FP}_{\text {blood }}$ and the $\mathrm{FP}_{\text {milk }}$, and it is therefore of relevance to verify whether former results from other species apply to modern, high-yielding dairy cows.

Water intake during lactation is assumed to be a combined response to feed-related stimuli and hypertonicity stimuli (Maltz et al., 1994). Kleyn et al. (1957) reported that increased ruminal fermentation following feed intake increased the amount of metabolites in blood and therefore partly counteracted the increase in $\mathrm{FP}_{\text {blood }}$ and $\mathrm{FP}_{\text {milk }}$ caused by the water intake.

The actual water intake (AWI) is thought to be of less importance compared with the water pool of the cows because this influences the homeostasis of $\mathrm{FP}_{\text {blood }}$ and subsequently $\mathrm{FP}_{\text {milk. }}$. For the purpose of this experiment, a new variable, the available water pool (AWP), was used to reflect the water balance, which was not, however, directly measurable in this experiment.

The objective was to study how dehydration and hydration influence packed cell volume $(\mathbf{P C V}), \mathrm{FP}_{\text {blood, }}$, and $\mathrm{FP}_{\text {milk }}$ and how this relates to the AWP of highproducing modern dairy cows.

\section{MATERIALS AND METHODS}

\section{Experimental and Laboratory Procedures}

All procedures involving cows were approved by the Danish Animal Experiments Inspectorate and complied with the Danish Ministry of Justice law no. 382 (June 10, 1987) and Acts 739 (December 6, 1988), and 333 (May 19, 1990) concerning animal experimentation and care of experimental animals.

The experiment began on March 15, 2004, at $1600 \mathrm{~h}$ and ended on March 20, 2004, at 0400 h. Four lactating Danish Holstein cows (second and third lactation, 92 to $212 \mathrm{~d}$ postpartum, 29.7 to $38.3 \mathrm{~kg}$ of energy-corrected

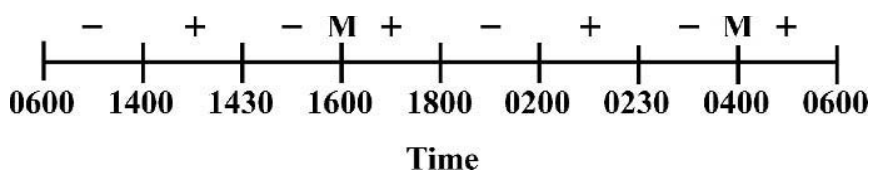

Figure 1. Watering scheme for 2 consecutive dehydration/rehydration sequences; - = free water deprivation, $+=$ free water available, $\mathrm{M}=$ milking.

milk/d) were used. The cows were kept and milked in an insulated tie-stall barn. They drank from individual water bowls provided with water meters on the supply pipes except during the rehydration sequence, where free water was served in a vessel. Free water intake was recorded at the same time as blood sampling.

The cows were fed a TMR of corn silage (42.9\%), grass silage $(26.9 \%)$, rapeseed cake $(12.9 \%)$, rolled barley (6.7\%), barley straw (5.3\%), beet molasses $(4.6 \%)$, and minerals $(0.7 \%)$. The DM content of the mixture was $46 \%$. Feed was mixed in the morning and fresh feed was served at $0800 \mathrm{~h}$. Cows had ad libitum access to feed, and feed vessels were refilled when needed. Feed was weighed and feed intake recorded at the same time as blood sampling.

The experiment was divided into 3 periods: control (38 h), dehydration/rehydration (4 consecutive sequences of $12 \mathrm{~h}$ each), and reconstitution ( $22 \mathrm{~h}$ ). The watering scheme for 2 dehydration/rehydration sequences is shown in Figure 1.

From d 1 at $1600 \mathrm{~h}$ to d 3 at $0600 \mathrm{~h}$ ( $38 \mathrm{~h}$ ), cows were allowed free water and food ad libitum (control). On d 3 at $0600 \mathrm{~h}$, free water was denied until $1400 \mathrm{~h}$. $(8 \mathrm{~h}=$ dehydration sequence (DE-) 1 . At $1400 \mathrm{~h}$, the cows were allowed free water ad libitum from a vessel for 30 min; and from 1430 to $1600 \mathrm{~h}$, free water was denied, followed by ad libitum free water intake until $1800 \mathrm{~h}$ (rehydration sequence (RE-) 1. At $1800 \mathrm{~h}$, free water was denied until 0200 ( $8 \mathrm{~h}=$ dehydration sequence 2 , DE-2). At $0200 \mathrm{~h}$, the cows were allowed free water ad libitum from a vessel for $30 \mathrm{~min}$, and from 0230 to 0400 $\mathrm{h}$, free water was denied, followed by ad libitum free water intake until $0600 \mathrm{~h}$ (rehydration sequence $2, \mathrm{RE}$ 2 ). This was repeated resulting in 4 dehydration/rehydration sequences (DE-1, RE-1, DE-2, RE-2, DE-3, RE3, DE-4, RE-4). From d 5 at 0600 h, cows were allowed ad libitum free water intake until d 6 at $0400 \mathrm{~h}(22$ $\mathrm{h}=$ reconstitution). This protocol simulated a situation with pasture for $8 \mathrm{~h}$ ( $\approx$ dehydration), water at arrival at the barn, no water when waiting for milking, and then water access for $2 \mathrm{~h}$ following milking $(\approx$ rehydration). Dry matter content of grass is lower than that of the TMR used here and water loss due to evaporation could be considerably higher during a real pasture situation. However, the protocol simulated periods of de- 
and rehydration whereby movement of water between body compartments could be studied.

The cows were milked at 12-h intervals, starting with the first cow at 0400 and $1600 \mathrm{~h}$, respectively. Individual composite milk samples were collected at each milking. During dehydration/rehydration sequences, the cows were thus milked $2 \mathrm{~h}$ after initiated rehydration.

Cows were fitted with sterile polyvinyl catheters (MicroRenathane, Braintree Scientific, Inc., Braintree, $\mathrm{MA}$ ) in one jugular vein $8 \mathrm{~h}$ before the first blood sampling. Heparin (25,000 IU/mL; Leo, Løvens Kemiske Fabrik, Ballerup, Denmark) was dissolved in a $\mathrm{NaCl}$ solution $(9 \mathrm{mg} / \mathrm{mL}$, osmolality $\sim 300 \mathrm{mOsm} / \mathrm{L}$; B. Braun Melsungen, Melsungen, Germany) to a concentration of $50 \mathrm{IU} / \mathrm{mL}$ and flushed through catheters following sampling to prevent coagulation within the catheter.

Blood samples were collected every hour, except during the 30-min rehydration following the 8-h dehydration sequence, when blood was collected at $0,15,30$, $60,90,120,150,180,210$, and 240 min after initiation of rehydration.

Blood samples collected in lithium-heparinized Vacutainers (BD, Plymouth, UK) were analyzed for osmolality using a cryoscopic osmometer (Osmomat 030, Gonotec, Berlin, Germany). The osmometer was calibrated using a solution of $\mathrm{NaCl}$ in $\mathrm{H}_{2} \mathrm{O}$ with an osmolality of $300 \mathrm{mOsm} / \mathrm{kg}$, according to the manufacturer's instructions. Samples for osmolality were kept at $4^{\circ} \mathrm{C}$ and analyzed within $48 \mathrm{~h}$ of sampling. All samples were analyzed in duplicate.

Blood samples collected in $\mathrm{K}_{2}$-EDTA Vacutainers (BD) were analyzed for PCV on a hemacytometer (CellDyn 3500, Abbott Laboratories A/S, Gentofte, Denmark). The hemacytometer was monitored with whole blood reference controls (Cell-Dyn 22 Control) according to the manufacturer's instructions. All samples were analyzed in duplicate within $8 \mathrm{~h}$ of sampling. One PCV value was discarded due to an error in a $\mathrm{K}_{2}$-EDTA Vacutainer.

Milk was analyzed for freezing point with an Advanced Cryomatic milk cryoscope, model 4C2 (Advanced Instruments Inc., Norwood, MA), which was calibrated according to the manufacturer's instructions. Milk was analyzed for protein and fat with a MilkoScan FT6000 (Foss Electric, Hillerød, Denmark).

Shebaita and Pfau (1983) found a linear relationship between the free water intake and total body water $(P$ $<0.01$ ) in mature Friesian bulls having a free water intake of 22 to $31 \mathrm{~L} / \mathrm{d}$. However, when correcting for water excretion in milk and using this equation on highyielding cows, total body water was underestimated compared with results of Shalit et al. (1991) and Woodford et al. (1984). To investigate the effect of the water pool, an approximated variable, the AWP, was therefore defined in the present experiment for each individual cow to reflect short-term changes in water balance during the dehydration/rehydration periods:

$$
\begin{aligned}
& \mathrm{AWP}_{t+1}=\mathrm{AWP}_{\mathrm{t}}+\Delta \text { water balance }_{t} \rightarrow_{\mathrm{t}+1},=\mathrm{AWP}_{\mathrm{t}} \\
& +\left(\text { total water intake }_{t} \rightarrow_{\mathrm{t}+1}-\text { water output }_{t} \rightarrow_{\mathrm{t}+1}\right)
\end{aligned}
$$

where tis time measured in hours, and $\Delta$ water balance $t \rightarrow t_{t+1}$ is the change in water balance from time $t$ to time $t+1 \mathrm{~h}$. The $\mathrm{AWP}_{0}$ (baseline at start of experiment) was set as being equal to the mean daily total water intake for each cow during the initial control and the reconstitution periods, assuming a water balance $=0$ in the undisturbed cow at this point. The $\mathrm{AWP}_{\mathrm{t}}$ was then calculated using single-cow hourly total water intake measurements.

To compare responses within and among cows, the $\mathrm{AWP}_{\mathrm{t}}$ and $\Delta$ water balance ${ }_{\mathrm{t}} \rightarrow_{\mathrm{t}+1}$ were subsequently calculated in relative numbers by division with the AW$\mathrm{P}_{\text {mean }}$; that is, the mean daily water intake during control and reconstitution periods, when the cows were assumed to be in water balance. Hence, the $\mathrm{AWP}_{\text {mean }}$ during the control and reconstitution periods was regulated to an index of 100 for each cow.

\section{Statistical Analyses}

Data were tested using the procedure PROC MIXED (SAS Institute, 1999). Cows, day/night, and periods (control, dehydration/rehydration, and reconstitution) were classified as class variables. Time of sampling was included as repeated measurement within the subject cow number in the models $1,3,4,5$, and 6 .

Free water and feed water intake were determined hourly, and free water and feed water intake thus represent intakes within the past hour. Actual free water intake was transformed with the cube root to approximate the normal distribution.

$$
\mathrm{Y}_{\mathrm{ijk}}=\mu+\operatorname{cow}_{\mathrm{i}}+\operatorname{period}_{\mathrm{j}}+\text { day/night }_{\mathrm{k}}+\varepsilon_{\mathrm{ijk}},
$$

where $\mathrm{Y}_{\mathrm{ijk}}=$ water intake of cow $\mathrm{i}$ at day/night $\mathrm{k}$ in period $\mathrm{j} ; \mu=$ overall mean, cow $_{\mathrm{i}}=$ random effect of cow $(i=1,2,3,4)$; period $_{j}=$ fixed effect of period $(j=$ control, dehydration/rehydration, reconstitution); day/night $\mathrm{k}_{\mathrm{k}}=$ fixed effect of day (0401 to $1600 \mathrm{~h}$ ) or night (1600 to $0400 \mathrm{~h})$; and $\varepsilon_{\mathrm{ijk}}=$ residual error $\sim \mathrm{N}\left(0, \sigma^{2}\right)$.

$$
\mathrm{Y}_{\mathrm{ij}}=\mu+\operatorname{cow}_{\mathrm{i}}+\operatorname{period}_{\mathrm{j}}+\varepsilon_{\mathrm{ij}}
$$

The yield ( $\mathrm{kg}$ of milk, $\mathrm{kg}$ of energy-corrected milk, fat percentage, and protein percentage) was tested by model 1 , where cow was used as random effect, and the variable, day/night, was excluded (model 2). 
The same model was used to test AWP, but cow was used as a repeated measurement (model [3]).

Packed cell volume was tested by model 4 where the variable water was AWI (fixed effect of total actual water intake within the previous hour) and cow was included as random effect.

$$
\mathrm{Y}_{\mathrm{ijk}}=\mu+\operatorname{cow}_{\mathrm{i}}+\operatorname{period}_{\mathrm{j}}+\text { water }_{\mathrm{k}}+\varepsilon_{\mathrm{ijk}} .
$$

Models 5 and 6 were reduced by backward stepwise selection, until only one effect of AWI/AWP remained.

The $\mathrm{FP}_{\text {blood }}$ was tested by model 5 with cow included as random effect and included effects of AWI at various times as shown. For model 6, the term AWP was substituted in place of AWI:

$$
\begin{aligned}
\mathrm{Y}_{\mathrm{ijk}}=\mu & +\operatorname{cow}_{\mathrm{i}}+\operatorname{period}_{\mathrm{j}}+\beta_{0}(\mathrm{AWI}-0)_{\mathrm{k}}+\beta_{1}(\mathrm{AWI}-1)_{\mathrm{k}} \\
& +\beta_{2}(\mathrm{AWI}-2)_{\mathrm{k}}+\beta_{3}(\mathrm{AWI}-3)_{\mathrm{k}}+\varepsilon_{\mathrm{ijk}},
\end{aligned}
$$

where $\mathrm{Y}_{\mathrm{ijk}}=\mathrm{FP}_{\text {blood }}$ for cow $\mathrm{i}$ during period $\mathrm{j}$ at time $\mathrm{k} ; \mu=$ overall mean; $\operatorname{cow}_{\mathrm{i}}=$ random effect of cow $(\mathrm{i}=1,2,3,4)$; period $_{j}=$ fixed effect of period $(j=$ control, dehydration/ rehydration, reconstitution); (AWI- 0$)_{\mathrm{k}}=$ fixed effect of AWI at time of blood sampling at time $\mathrm{k} ;(\mathrm{AWI}-1)_{\mathrm{k}}=$ fixed effect of AWI $1 \mathrm{~h}$ before blood sampling at time $\mathrm{k}$; (AWI-2) $)_{\mathrm{k}}=$ fixed effect of AWI $2 \mathrm{~h}$ before blood sampling at time $\mathrm{k} ;(\mathrm{AWI}-3)_{\mathrm{k}}=$ fixed effect of AWI $3 \mathrm{~h}$ before blood sampling at time $\mathrm{k}$; and $\varepsilon_{\mathrm{ijk}}=$ residual error $\sim \mathrm{N}\left(0, \sigma^{2}\right)$.

The $\mathrm{FP}_{\text {milk }}$ was tested by model 5 where cow was included as random effect, the term AWI was substituted by the term $\mathrm{FP}_{\text {blood }}$, and the term "before blood sampling" was substituted by the term "before milk sampling" (model 7). Model 7 was reduced as model 5.

\section{RESULTS}

\section{Water Intake and AWP}

Diurnal variations in feed water and free water uptake for the individual cows are shown in Figure 2. Mean hourly free water, feed water, and total water intakes during the dehydration/rehydration period did not differ from the intakes in control and reconstitution periods $(P=0.985, P=0.998$, and $P=0.986$, respectively). We did not observe any difference in water intakes during the day compared with the night $(P=$ $0.611, P=0.776$, and $P=0.614$, respectively) (model 1). Mean hourly free water, feed water, and total water intake are presented in Table 1. Free water intake for individual cows was strongly correlated with feed water intake $(P<0.001)$.

During rehydration sequences, free water intake was larger $(P<0.001)$ during the first $15 \mathrm{~min}$ than the following $15 \mathrm{~min}$, least squares means being 36.6 and $1.1 \pm 1.4 \mathrm{~kg}$, respectively.

Although variations in AWP were large within the de- and rehydration sequences (Figure 3), there were no statistical differences in the mean hourly AWP compared with the control and reconstitution periods $(P=$ 0.264) (model 3). It seemed, however, that during the control period, the AWP was lower during the night compared with the day (Figure 3). During the dehydration/rehydration period, variations in AWP seemed to reduce with increasing sequences.

\section{Milk Yield}

Milk yield per milking was similar during the control and reconstitution periods $(P=0.087)$. Milk yield increased during the dehydration/rehydration period compared with the control period $(P=0.011)$; however, no difference was observed between the dehydration/ rehydration period and the reconstitution period $(P=$ 0.660) (model 2). Values are presented in Table 1.

When milk yield was corrected for energy content $(P$ $<0.001$ ), similar relationships were observed, with the exception that energy-corrected milk yield in the control period was significantly lower than during the reconstitution period $(P=0.013)$.

The fat percentage of the milk increased during the reconstitution period compared with both the control and dehydration/rehydration periods $(P=0.009$ and $P=0.005$, respectively) (model 2 ). No difference was observed between the control and dehydration/rehydration periods $(P=0.780)$. Protein percentage did not differ between periods $(P=0.127)$.

\section{PCV and $\mathrm{FP}_{\text {blood }}$}

Packed cell volume did not differ between periods $(P=0.710)$, but decreased by $0.061 \%$ per $\mathrm{kg}$ of water intake $(P<0.001)$ (model 4$)$. Additionally, PCV differed between cows $(P<0.001)$.

The $\mathrm{FP}_{\text {blood }}$ was not affected by the AWI $0,1,2$, and $3 \mathrm{~h}$ before blood sampling (model 5 ) having $P$ values of $0.11,0.10,0.34$, and 0.29 , respectively. The $\mathrm{FP}_{\text {blood }}$ increased by $0.0003^{\circ} \mathrm{C}$ per $1 \%$ increase in the AWP at the time of blood sampling $(P<0.001)$ (Figure 3$)$, but was not affected by the different watering pattern of cows between periods $(P=0.530)$ (model 6$)$, with mean hourly $\mathrm{FP}_{\text {blood }}$ being $-0.5631 \pm 0.0086^{\circ} \mathrm{C}$.

Examining the correlation between $\mathrm{FP}_{\text {blood }}$ and the AWP $0,1,2$, and $3 \mathrm{~h}$ before blood sampling at cow level showed differing results for individual cows (Table 2); however, in all cows, $\mathrm{FP}_{\text {blood }}$ was correlated with AWP at time of blood sampling. Further, for 3 cows, $\mathrm{FP}_{\text {blood }}$ was significantly correlated with AWP at $1 \mathrm{~h}$ before 

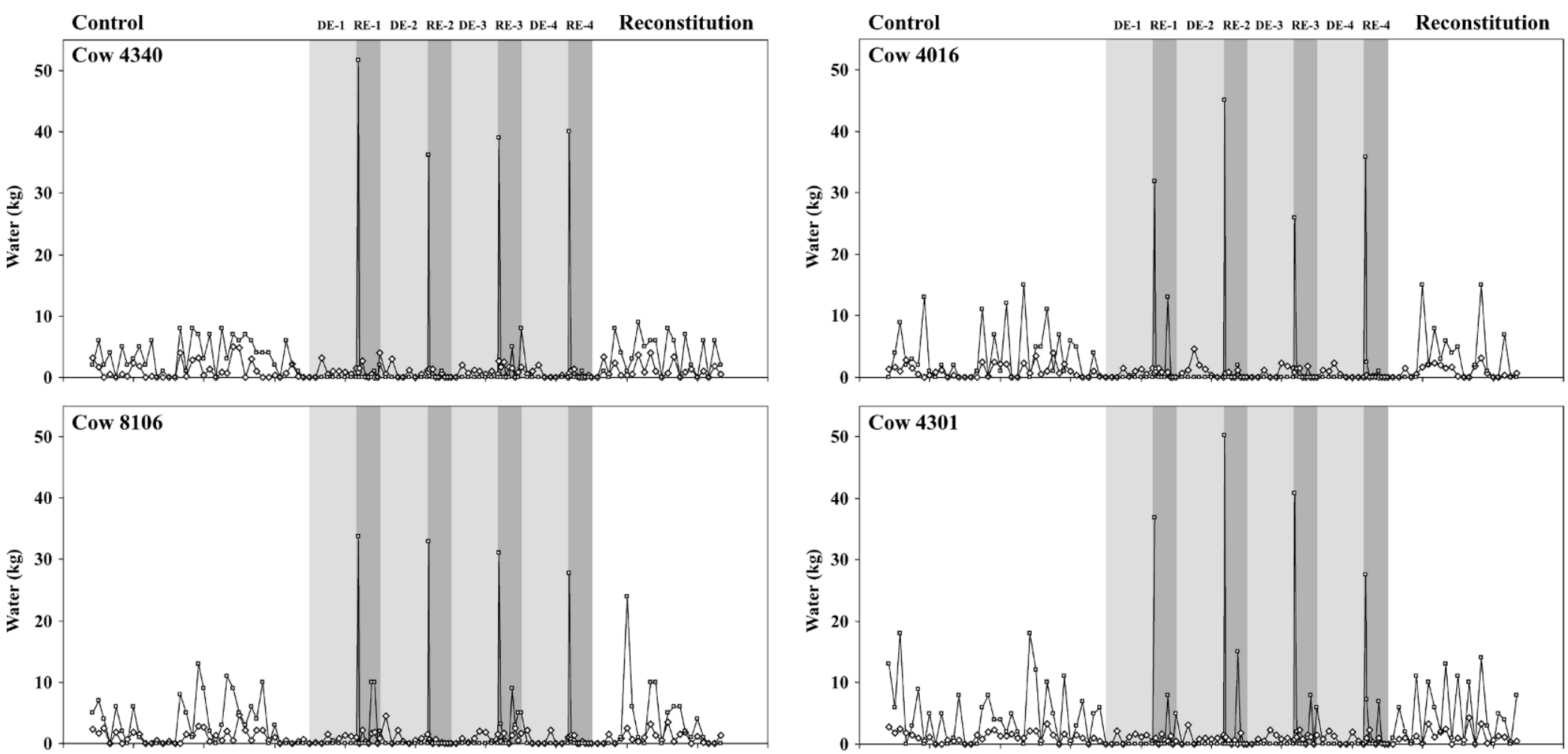

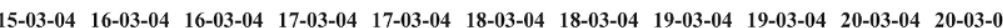

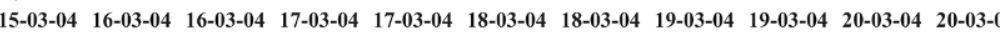

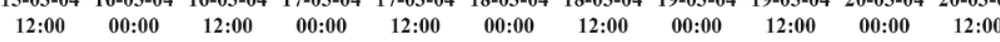

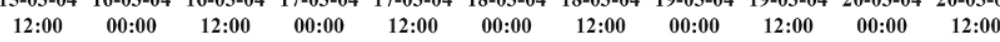

Date and time

Date and time

Figure 2. Diurnal variation in feed water $(\diamond)$ and free water uptake $(\square)$ for individual cows. Light gray shading indicates dehydration sequences $(\mathrm{DE}-1$ to DE-4; $8 \mathrm{~h}$ each), and dark gray shading indicates rehydration sequences (RE-1 to RE-4; 30 min with water ad libitum, 90 min with denied access to water, and 120 min with water ad libitum). 
Table 1. Mean values and standard deviations for water intake, available water pool (AWP), milk yield, packed cell volume $(\mathrm{PCV})$, freezing point of blood $\left(\mathrm{FP}_{\text {blood }}\right)$ and milk $\left(\mathrm{FP}_{\text {milk }}\right)$ throughout the experimental period. ${ }^{1}$

\begin{tabular}{lcccll}
\hline & $\mathrm{n}^{1}$ & Mean & $\mathrm{SD}$ & Period & Day/night \\
\hline Free water, kg/h & 432 & 3.77 & 7.84 & $\mathrm{NS}$ & $\mathrm{NS}$ \\
Feed water, kg/h & 432 & 1.07 & 1.15 & $\mathrm{NS}$ & $\mathrm{NS}$ \\
Total water, kg/h & 432 & 4.84 & 8.50 & $\mathrm{NS}$ & $\mathrm{NS}$ \\
AWP & 436 & 97.87 & 11.21 & $\mathrm{NS}$ & \\
Milk, kg/d & 40 & 17.51 & 2.08 & $* * *$ & \\
Milk, kg of ECM/d ${ }^{2}$ & 40 & 16.71 & 2.02 & $* * *$ & \\
Fat, $\%$ & 40 & 3.71 & 0.34 & $*$ & \\
Protein, $\%$ & 40 & 3.28 & 0.16 & $\mathrm{NS}$ & \\
PCV, $\%$ & 435 & 22.98 & 1.78 & $\mathrm{NS}$ & \\
$\mathrm{FP}_{\text {blood, }}{ }^{\circ}{ }^{\circ} \mathrm{C}$ & 436 & -0.5631 & 0.0086 & $\mathrm{NS}$ & \\
$\mathrm{FP}_{\text {milk }}{ }^{\circ} \mathrm{C}$ & 36 & -0.5249 & 0.0041 & $\mathrm{NS}$ & \\
\hline
\end{tabular}

${ }^{1}$ Cows $(\mathrm{n}=4)$ were sampled for $108 \mathrm{~h}$, which gives 432 intervals and 436 hourly samples including time $=$ 0 . One sample was missing for PCV. Cows were milked 10 times each $(n=40)$, but the initial value for $\mathrm{FP}_{\text {milk }}$ was not used $(\mathrm{n}=36)$.

${ }^{2}$ Milk yield in kilograms of energy-corrected milk per day.

${ }^{3}$ Values for $\mathrm{FP}_{\text {blood }}$ were calculated only from hourly samples.

$* P<0.05, * * P<0.01, * * * P<0.001$.

blood sampling, whereas a correlation with the AWP 2 and $3 \mathrm{~h}$ prior was obtained for 2 cows only. Correlations were relatively small and indicate a large variation within measurements and may or may not have biological relevance.

The intake of water following the 8-h dehydration sequence caused an immediate increase in the $\mathrm{FP}_{\text {blood }}$ within 15 min of water intake (Table 3 ), which remained elevated over the next 30 min after water intake, and normalized over the next $30 \mathrm{~min}$. The same pattern was observed during rehydration during the day and at night. The PCV changed in a manner opposite of $\mathrm{FP}_{\text {blood, }}$, with an immediate significant decrease within the first $15 \mathrm{~min}$ and then stabilization up to $30 \mathrm{~min}$ after water intake and normalization during the following 30 min. Means of PCV of the different intervals were not tested against each other, but only as to whether values changed within the given interval.

The $\mathrm{FP}_{\text {blood }}$ decreased less in response to dehydration on the second experimental day (dehydration sequences DE-3 and DE-4) compared with the first experimental day (DE-1 and DE-2) $(P<0.001)$, whereas during the rehydration sequences, $\mathrm{FP}_{\text {blood }}$ increased slightly more on the second day compared with the first day $(P<$ 0.001) (Table 4).

These latter results were also observed when analyzing cows individually, with $P<0.001$ to 0.035 during dehydration and rehydration, respectively (data not shown). Whether these effects were associated with the cows' adjustment to repetitive dehydration and rehydration or confounded with day is unclear, and cannot be explained by this experiment.

During dehydration at night (DE-2 and DE-4), $\mathrm{FP}_{\text {blood }}$ decreased faster than in daytime (DE-1 and DE-3) $(P$
$<0.001)$ and increased more during rehydration $(P<$ $0.001)$.

$\mathrm{FP}_{\text {milk }}$

A linear correlation was found between $\mathrm{FP}_{\text {milk }}$ and $\mathrm{FP}_{\text {blood }}$ measured $1 \mathrm{~h}$ before milking $(P=0.020)$, but not with $\mathrm{FP}_{\text {blood }}$ measured at time of milking or 2 or 3 $\mathrm{h}$ prior. The same positive correlation was found in the control, dehydration/rehydration, and reconstitution periods (model 7 ). The mean $\mathrm{FP}_{\text {milk }}$ was $-0.5249 \pm$ $0.0041^{\circ} \mathrm{C}(\mathrm{n}=36)$.

When investigating the simple correlation between $\mathrm{FP}_{\text {blood }}$ and $\mathrm{FP}_{\text {milk }}$ for individual cows, however, deviations appeared (Table 5). For cows 4016 and 4340, the results were in agreement with the above, whereas for cow 8106 , the $\mathrm{FP}_{\text {milk }}$ was correlated $(\mathrm{r}=0.780, P=$ 0.013) with $\mathrm{FP}_{\text {blood }} 3 \mathrm{~h}$ before milk sampling and for cow 4301, no correlation could be established.

The results revealed that a large water intake following dehydration increased the $\mathrm{FP}_{\text {milk }}$, albeit with a 1-h delay. During dehydration, the $\mathrm{FP}_{\text {blood }}$ and the $\mathrm{FP}_{\text {milk }}$ decreased. Upon rehydration, it would take $\mathrm{FP}_{\text {blood }} 6.3$, $6.9,2.3$, and $3.9 \mathrm{~h}$ to increase to the control level for RE-1, RE-2, RE-3, and RE-4, respectively, when assuming the linear relation found is acceptable within the given intervals. The cows were milked $2 \mathrm{~h}$ after initiated rehydration, and due to delayed water transfer time, $\mathrm{FP}_{\text {milk }}$ was therefore lower than the level before the initiated dehydration.

\section{DISCUSSION}

\section{Water Intake and AWP}

In the present experiment we did not find any influence on daily water intake, whether the cows had access 


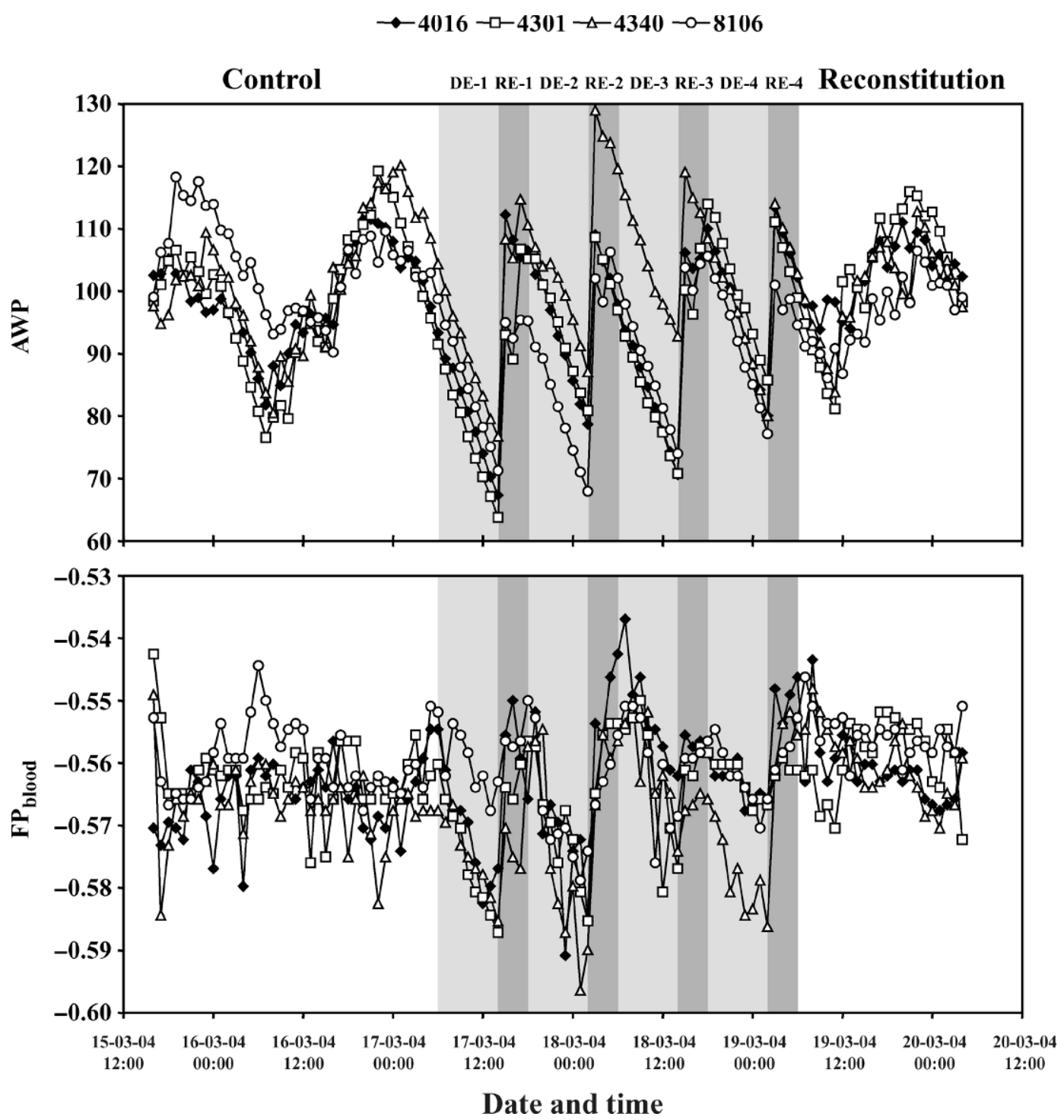

Figure 3. Diurnal variation in the available water pool (AWP) and freezing point of blood $\left(\mathrm{FP}_{\mathrm{blood}}\right)$ for individual cows (cows 4016 , 4301 , 4340, and 8106). Light gray shading indicates dehydration sequences of $8 \mathrm{~h}$ (DE-1 to DE-4), and dark gray shading indicates rehydration sequences (RE-1 to RE-4; 30 min with water ad libitum, 90 min with denied access to water, and 120 min with water ad libitum).

Table 2. Correlations within and across cows between the freezing point of blood $\left(\mathrm{FP}_{\mathrm{blood}}\right)$ and the available water pool (AWP) $0,1,2$, and $3 \mathrm{~h}$ before blood sampling.

\begin{tabular}{llllll}
\hline & & \multicolumn{4}{c}{ Available water pool } \\
\cline { 3 - 6 } Cow & $\mathrm{n}^{1}$ & AWP-0 & AWP-1 & AWP-2 & AWP-3 \\
\hline 4016 & 106 & $0.255^{* *}$ & $0.142^{\mathrm{NS}}$ & $0.031^{\mathrm{NS}}$ & $-0.074^{\mathrm{NS}}$ \\
4301 & 106 & $0.602^{* * *}$ & $0.532^{* * *}$ & $0.402^{* * *}$ & $0.250^{* * *}$ \\
4340 & 106 & $0.283^{* *}$ & $0.281^{* *}$ & $0.180^{\mathrm{NS}}$ & $0.124^{\mathrm{NS}}$ \\
8106 & 106 & $0.296^{* *}$ & $0.300^{* *}$ & $0.261^{* *}$ & $0.224^{*}$ \\
All & 424 & $0.288^{* * *}$ & $0.239^{* * *}$ & $0.149^{* *}$ & $0.065^{\mathrm{NS}}$ \\
\hline
\end{tabular}

${ }^{1}$ The first 3 of 109 hourly blood samples per cow could not be used to construct AWP-3.

$* P<0.05, * * P<0.01, * * * P<0.001$. 
Table 3. Changes in the freezing point of blood $\left(\mathrm{FP}_{\text {blood }}\right)$ and packed cell volume (PCV) per hour during the first hour after initiated rehydration of $1.5 \mathrm{~h}$ within each of four 12 -h periods for each of 4 cows.

\begin{tabular}{|c|c|c|c|c|c|c|c|}
\hline \multirow{2}{*}{$\begin{array}{l}\text { Interval, } \\
\text { min }\end{array}$} & \multirow[b]{2}{*}{$n^{1}$} & \multicolumn{3}{|c|}{$\Delta \mathrm{FP}_{\text {blood }},{ }^{\circ} \mathrm{C} / \mathrm{h}$} & \multicolumn{3}{|c|}{$\Delta \mathrm{PCV}, \% / \mathrm{h}$} \\
\hline & & Estimate & $\mathrm{SE}$ & $P$ & Estimate & $\mathrm{SE}$ & $P$ \\
\hline $0-15$ & 32 & 0.0225 & 0.0092 & 0.021 & -3.425 & 1.016 & 0.002 \\
\hline $15-30$ & 32 & 0.0258 & 0.0062 & $<0.001$ & -1.450 & 0.846 & 0.098 \\
\hline $30-60$ & 32 & 0.0058 & 0.0029 & 0.054 & 0.450 & 0.386 & 0.254 \\
\hline
\end{tabular}

${ }^{1}$ Sixteen regression lines were constructed from 32 measuring points in each interval.

to water continuously during the day or whether they were deprived access to water for $8 \mathrm{~h}$ followed by access to water for rehydration for shorter periods ( $2 \mathrm{~h}$ in total).

The 8-h dehydration followed by rehydration had no reducing effect on the milk yield when expressed as kilograms of milk or of energy-corrected milk, the former reported by Castle and Watson (1973).

During rehydration sequences, the free water intake occurred mainly within the first 15 min after water had been offered, which is in agreement with Bianca (1970), who reported cows drinking water equivalent to $15 \%$ of BW within 4 min following dehydration. Warner and Stacy (1968) demonstrated that following dehydration, sheep with access to water only once daily drank 90 to $100 \%$ of their free water intake immediately after serving, and if they drank more, they did so within the next 15 to $30 \mathrm{~min}$. This was consistent with the present observations, where $97 \%$ of the free water intake occurred within the first $15 \mathrm{~min}$ after initiated rehydration.

To include the previous water pool of the cow, the approximated AWP was introduced. In this experiment, body water was not measured and because the calculation of body water from body weight also includes errors, the assumption that the mean AWP is equal to the mean daily water intake seems acceptable; Shebaita and Pfau (1983) found a linear relation between the free water intake and total body water of bulls $(P<$ $0.01)$. Although water intake and body water is higher of dairy cows than of bulls, we expect a similar relationship.

The relative changes in the AWP were of interest, and the AWP values were calculated relative to the size of their mean AWP. In the calculations, mean water loss was set as a constant for each cow; hence, mean hourly input equaled mean hourly output throughout the experiment. Although Maltz et al. (1994) described the physiological responses of milk production, urine, feces, respiration, and cutaneous evaporation as continuous output, these are likely to change with the water pool of the cow, especially throughout the dehydration and rehydration sequences, thus causing errors between the calculated value and the true value. For the purpose of this study, however, the calculated AWP seems to be a reasonable approximation for the water balance of the cows.

It seemed that during the control period, the AWP was lower during the night compared with the day, indicating diurnal variation in the fluid balance. During the dehydration/rehydration period, variations in AWP seemed to become smaller with increasing sequences, indicating an adaptation in fluid balance to dehydration and rehydration, most likely caused by the rumen functioning as a water reservoir.

Table 4. Regression coefficients of the freezing point of blood $\left(\mathrm{FP}_{\text {blood }}\right)$ per hour during the dehydration/ rehydration sequences. ${ }^{1}$

\begin{tabular}{|c|c|c|c|c|c|c|c|}
\hline \multirow[b]{2}{*}{ Effect } & \multirow[b]{2}{*}{ Sequences } & \multicolumn{3}{|c|}{ Dehydration } & \multicolumn{3}{|c|}{ Rehydration } \\
\hline & & $\mathrm{n}^{2}$ & $\mathrm{r},{ }^{\circ} \mathrm{C} / \mathrm{h}$ & $\mathrm{SE},{ }^{\circ} \mathrm{C} / \mathrm{h}$ & $\mathrm{n}^{3}$ & $\mathrm{r},{ }^{\circ} \mathrm{C} / \mathrm{h}$ & $\mathrm{SE},{ }^{\circ} \mathrm{C} / \mathrm{h}$ \\
\hline Day 1 & 1 and 2 & 72 & $-0.0035^{\mathrm{a}}$ & 0.0003 & 40 & $0.0042^{\mathrm{a}}$ & 0.0006 \\
\hline Day 2 & 3 and 4 & 72 & $-0.0017^{\mathrm{b}}$ & 0.0003 & 40 & $0.0044^{\mathrm{b}}$ & 0.0006 \\
\hline Day & 1 and 3 & 72 & $-0.0022^{\mathrm{a}}$ & 0.0003 & 40 & $0.0041^{\mathrm{a}}$ & 0.0006 \\
\hline Night & 2 and 4 & 72 & $-0.0030^{b}$ & 0.0003 & 40 & $0.0045^{\mathrm{b}}$ & 0.0006 \\
\hline
\end{tabular}

${ }^{\mathrm{a}, \mathrm{b}}$ Significantly different within each effect within column $(P<0.001)$.

${ }^{1}$ Dehydration/rehydration sequences 1 to 4 were within consecutive 12 -h periods including $8 \mathrm{~h}$ without water (dehydration), 0.5 -h access to water, $1.5 \mathrm{~h}$ without water, and 2 -h access to water (rehydration).

${ }^{2}$ Samples were used from hourly samples at time $0,1, \ldots 8 \mathrm{~h}$ per cow per dehydration sequence $(\mathrm{n}=4$ $\times 2 \times 9=72)$

${ }^{3}$ Samples were used from hourly samples at time $0,1, \ldots 4 \mathrm{~h}$ per cow per rehydration sequence $(\mathrm{n}=4$ $\times 2 \times 5=40)$. 
Table 5. Correlations between the freezing point of milk and blood $\left(\mathrm{FP}_{\text {milk }}\right.$ and $\left.\mathrm{FP}_{\text {blood }}\right) 0,1,2$, and $3 \mathrm{~h}$ before milk sampling.

\begin{tabular}{lcllrl}
\hline Cow & $\mathrm{n}$ & $\mathrm{FP}_{\text {blood }}-0$ & $\mathrm{FP}_{\text {blood }}-1$ & $\mathrm{FP}_{\text {blood }}-2$ & $\mathrm{FP}_{\text {blood }}-3$ \\
\hline 4016 & 9 & $0.204^{\mathrm{NS}}$ & $0.708^{*}$ & $-0.080^{\mathrm{NS}}$ & $0.251^{\mathrm{NS}}$ \\
4301 & $8^{1}$ & $0.210^{\mathrm{NS}}$ & $0.202^{\mathrm{NS}}$ & $0.339^{\mathrm{NS}}$ & $0.418^{\mathrm{NS}}$ \\
4340 & 9 & $0.608^{\mathrm{NS}}$ & $0.869^{* *}$ & $0.134^{\mathrm{NS}}$ & $0.211^{\mathrm{NS}}$ \\
8106 & 9 & $0.267^{\mathrm{NS}}$ & $0.344^{\mathrm{NS}}$ & $0.599^{\mathrm{NS}}$ & $0.780^{*}$ \\
All & 35 & $0.427^{*}$ & $0.619^{* * *}$ & $0.231^{\mathrm{NS}}$ & $0.390^{*}$ \\
\hline
\end{tabular}

${ }^{1}$ One milk sample of cow 4301 was discarded as an outlier.

$* P<0.05, * * P<0.01, * * * P<0.001$.

\section{PCV}

Values for PCV were lower than described by Ryan (1971), likely due to an increased water intake due to a higher production level.

Mean hourly PCV did not differ between control, dehydration/rehydration, and reconstitution periods, which was in agreement with Little et al. (1984), who found no significant difference in PCV between dehydrated and control British Friesian cows until $62 \mathrm{~h}$ after initiated dehydration. Moreover, PCV did not change significantly during rehydration.

According to Maltz et al. (1994), no diurnal pattern was observed for PCV when the cows were allowed their natural drinking behavior. In the present experiment, however, it was clear that water intake had an acute (30-min) negative effect on PCV, indicating that water intake caused short-term hemodilution. The reason for only observing this 15-min dilution of the blood volume is likely the fact that water is recycled back to the rumen through an increased amount of hypotonic saliva or moved to extravascular compartments.

This means that large water intakes only increase the blood volume within $15 \mathrm{~min}$, and an increase in $\mathrm{FP}_{\text {blood }}$ is therefore not caused by increased blood volume.

\section{FP $_{\text {blood }}$}

The mean hourly $\mathrm{FP}_{\text {blood }}$ did not differ between the control, dehydration/rehydration, and reconstitution periods. It was clear, however, that the 8-h dehydration caused a decrease in the $\mathrm{FP}_{\text {blood }}$, which was consistent with results of Choshniak et al. (1984), whereas rehydration caused an increase (Dahlborn et al., 1997). This was in contrast to Little et al. (1984) who found no change until $24 \mathrm{~h}$ after initiated deprivation.

Regression coefficients were based on the assumption that changes in the $\mathrm{FP}_{\text {blood }}$ during dehydration and rehydration were linear within the used interval because the main driving force of water across the rumen epithelium was the osmotic difference between rumen and blood (Silanikove, 1989; Tabura et al., 1990).
During rehydration sequences, $\mathrm{FP}_{\text {blood }}$ rose significantly during the first $30 \mathrm{~min}$ after initiation due to the large free water intake, which was in agreement with results from experiments with sheep (Dahlborn and Holtenius, 1990). Further, the PCV only decreased within the first $15 \mathrm{~min}$, both indicating rapid hemodilution. Silanikove (1989) showed that dilution and rapid expansion of plasma were prevented by a parallel increase in hypotonic saliva secretion, which, together with the fact that $97 \%$ of the free water intake occurred within the first 15 min, was the likely reason why PCV stabilized after $15 \mathrm{~min}$.

Regression coefficients were numerically lower during the day compared with the night. Even though no difference in feed intake between day and night was shown, the most likely reason could be the counteracting effect of increased concentration of fermented products in the rumen (Scott, 1975) occurring because of an increased feed intake during the day, causing an increase in rumen content osmolality. An increased intake could be due to 2 factors, namely the higher day activity of the cows and the fact that the TMR was only mixed in the morning, which probably made the feed more attractive during the day (DeVries et al., 2003).

Moreover, a day-to-day effect was shown for the dehydration/rehydration sequences. However, due to the method of the present experiment, it was not possible to determine whether this effect was caused by physiological adjustments or confounded with day. The cows were kept in an isolated tie-stall barn under relatively constant conditions during the experiment, and it therefore seemed probable that the cows were able to adjust to repetitive dehydration and rehydration; however, further research is needed. A possible explanation could be that the large amount of water in the rumen from the previous rehydration sequence acted as a reservoir to maintain homeostasis (Silanikove and Tadmor, 1989).

The $\mathrm{FP}_{\text {blood }}$ was assumed positively related to AWI; however, no significant relation was found between them. The $\mathrm{FP}_{\text {blood }}$ changed positively with the AWP at time of blood sampling, supporting the hypothesis that 
the rumen serves as water reservoir (Silanikove, 1989; Silanikove and Tadmor, 1989), and that the main driving force of water flux across the rumen was the osmotic difference between rumen and blood (Silanikove, 1989; Tabura et al., 1990). Additionally, the absorption of VFA from the rumen was thought to stimulate the absorption of water due to the high correlation between the absorption of water and VFA (Tabura et al., 1990)

This means that although dehydration and rehydration of the cows had no effect on the mean hourly $\mathrm{FP}_{\text {blood }}$ throughout the experiment, dehydration and rehydration caused decreasing and increasing $\mathrm{FP}_{\text {blood }}$, respectively. It was clear that the rumen served as a temporary reservoir of water, thereby reducing hemodilution due to large water intakes.

\section{$\mathrm{FP}_{\text {milk }}$}

The mean $\mathrm{FP}_{\text {milk }}$ in the present experiment was $-0.5249^{\circ} \mathrm{C}$, which was consistent with a Dutch study (Slaghuis, 2001) involving 10 farms, where the mean $\mathrm{FP}_{\text {milk }}$ of original morning and evening milks were -0.5219 and $-0.5257^{\circ} \mathrm{C}$, respectively.

The large AWI $2 \mathrm{~h}$ before milking following the dehydration sequences had no direct effect on the $\mathrm{FP}_{\text {milk}}$, whereas AWP may be more directly related. However, no direct relationship was found between the AWP and the $\mathrm{FP}_{\text {milk }}$. Nevertheless, the AWP at sampling time positively changed the $\mathrm{FP}_{\text {blood }}$, which then positively changed the $\mathrm{FP}_{\text {milk }} 1 \mathrm{~h}$ later. It must be taken into account that water intake had been summed within the past hour, and because the exact time of free water and feed intake had not been noted, it was unclear when the cows took in water during that hour.

There is a linear relation between the osmolality of the rumen fluid and the net water transport to the vascular department (Warner and Stacy, 1972; Tabura et al., 1990). Silanikove and Tadmor (1989) showed that tritiated water activity equilibrated between the reticulorumen and the blood within $4.5 \pm 0.5 \mathrm{~h}$ in hydrated cows and $6.0 \pm 0.4 \mathrm{~h}$ in cows dehydrated for 24 h. Within 20 min of infusion of tritiated water into the blood, 20 to $35 \%$ of the plasma level was measured in milk (Linzell and Peaker, 1971a). This supported the equilibrium delay obtained in our study. Dahlborn et al. (1997), on the contrary, showed simultaneous changes in the osmolality of blood and milk of camels, which may have a different passage rate, but the experiment included only 2 animals.

The true mechanisms involved in the water flux from blood to milk are yet unknown. According to Linzell and Peaker (1971b), the permeability to ${ }^{3} \mathrm{H}_{2} \mathrm{O}$ varied little in the different parts of the udder, whereas Peaker (1977) later showed that the water flow in the gland was established across the secretory epithelium rather than the duct epithelium. A possible mechanism is the aquaporin-1 water channel, which is important in osmotic water movement across cell membranes of epithelial membranes. Recent findings in humans confirmed a moderate expression of aquaporin-1 in the breast epithelium; that is, in the basolateral membranes of the mammary ducts and glands and in endothelial barriers where it might be involved in milk production (Mobasheri and Merples, 2004). It has further been suggested that the intracellular accumulation of chloride, via sodium, potassium, and chloride cotransport across the basolateral membrane, is the driving force for the secretion of ions and water across the apical membrane (Shennan and Peaker, 2000).

This means that, under these experimental circumstances, $\mathrm{FP}_{\text {milk }}$ was not affected by dehydration and rehydration as suggested. We found that changes in $\mathrm{FP}_{\text {milk }}$ are delayed for up to $1 \mathrm{~h}$ with respect to $\mathrm{FP}_{\text {blood; }}$; however, the mechanisms responsible for this delay are not clear.

\section{Correlation Between $\mathrm{FP}_{\text {blood }}$ and $\mathrm{FP}_{\text {milk }}$}

Despite the fact that $\mathrm{FP}_{\text {milk }}$ changed positively with $\mathrm{FP}_{\text {blood }} 1 \mathrm{~h}$ before milk sampling, correlations between $\mathrm{FP}_{\text {milk }}$ and $\mathrm{FP}_{\text {blood }} 0,1,2$, and $3 \mathrm{~h}$ before milk sampling yielded ambiguous results. Cows 4016 and 4340 were consistent with earlier results, whereas cow 8106 only showed a highly significant correlation between the $\mathrm{FP}_{\text {milk }}$ and the $\mathrm{FP}_{\text {blood }} 3 \mathrm{~h}$ before milk sampling. Cow 4301 showed no significant correlation. Correlations were only based on 8 to 9 observations per cow and therefore, were easily affected by small variations, which was probably the reason for the insignificant results.

\section{Perspectives}

The freezing point of milk increases during the summer compared with the winter, which is reportedly caused by increased water intakes due to increased temperatures and sunshine hours, and it is especially pronounced when cows are grazing without access to water.

In 2003, $80 \%$ of the Danish yield-controlled herds practiced summer grazing (Trinderup and Enemark, 2003). Another Danish study from 2003 of grazing dairy cows of large breeds showed that, on conventional and organic farms, grass constituted on average 30 and $39 \%$ of the daily energy intake, respectively, through the grazing season. In 2002, the values were 42 and $39 \%$ for the large breeds and 43 and $56 \%$ for Jersey, respectively (Bligaard and Nielsen, 2004). The internal water con- 
tent of grass is released quickly in the rumen, and it is suggested that it circulates and transits as rapidly as external water (Cabrera Estrada et al., 2004). Hence, with grass having water content of 80 to $83 \%$, a relatively large portion of the daily total water intake is obtained directly through grazing. Grazing cows will consequently have a more or less continuous intake of feed water when free water access is restricted, whereas the cows in the present experiment only had access to a $46 \%$ DM TMR during dehydration. Additionally, free water intake increases with increasing silage DM content, replacing silage water at a rate less than one (Dewhurst et al., 1998); that is, the total water intake increases when cows are fed fresh grass compared with a TMR of silages and concentrate.

Castle and Watson (1973) offered cows free water both in the field and during milking and observed that $98.7 \%$ of the total daily water intake was consumed in the field. The cows in the present experiment drank ad libitum from water bowls except during the de- and rehydration sequences. It was obvious from the drinking pattern of the cows in the present experiment that cows deprived of access to water for up to $8 \mathrm{~h}$ have substantially increased drinking bouts compared with cows having ad libitum access to water. Consequently, only minor diurnal fluctuations would be expected in the AWP of cows under conditions with ad libitum access to water.

Daily free water intake on pasture is positively related to the number of sunshine hours (MacFarlane and Howard, 1966; Castle and Watson, 1973; Stockdale and King, 1983), and grazing cows have a shorter water turnover time compared with stall-fed cows. Siebert and MacFarlane (1969) found an increase in body water during the summer compared with the winter and Lee et al. (1976) suggested that the observed hemodilution at increased ambient temperatures could be explained by more water being transported in the circulatory system for evaporative cooling. The results of those studies support the hypothesis that increased water intake due to increased temperature and sunshine hours results in an increase in $\mathrm{FP}_{\text {blood }}$ and consequently, $\mathrm{FP}_{\text {milk. }}$.

From the present experiment, it was clear that $\mathrm{FP}_{\text {blood }}$ rose with increases in AWP. However, during the 8-h dehydration sequence, the $\mathrm{FP}_{\text {blood }}$ decreased more than it increased during the 2 -h rehydration sequences before milking. Due to this and the fact that changes in the $\mathrm{FP}_{\text {milk }}$ were delayed with respect to the $\mathrm{FP}_{\text {blood, }}$, $\mathrm{FP}_{\text {milk }}$ did not exceed control values during the dehydration/rehydration period. If, however, the day-to-day effect observed was caused by the cows' adjustments, $\mathrm{FP}_{\text {milk }}$ could exceed the quality limit of $-0.516^{\circ} \mathrm{C}$ when the body water pool increases above the levels obtained in this experiment.

\section{CONCLUSIONS}

The $\mathrm{FP}_{\text {blood }}$ was found to change positively with changes in AWP. During dehydration, the $\mathrm{FP}_{\text {blood }}$ therefore decreased, subsequently rising significantly during the first $30 \mathrm{~min}$ after initiated rehydration, and normalizing thereafter. The $\mathrm{FP}_{\text {milk }}$ was also positively correlated with the $\mathrm{FP}_{\text {blood }}$ measured $1 \mathrm{~h}$ before milking, but even with $2 \mathrm{~h}$ from initiated rehydration to milking, $\mathrm{FP}_{\text {blood }}$ and $\mathrm{FP}_{\text {milk }}$ did not increase enough to reach the control level due to a delay in transfer time of water from blood to milk. Therefore, there is not a simultaneous change in the $\mathrm{FP}_{\text {blood }}$ associated with actual water intake.

The $\mathrm{FP}_{\text {blood }}$ decreased and increased more slowly during the day compared with the night, probably due to the counteracting effect of increased fermentation in the rumen during the day. Additionally, during the second day of dehydration/rehydration, $\mathrm{FP}_{\text {blood }}$ decreased more slowly and increased faster compared with the first day. It is uncertain, however, whether this effect was due to the cows' adjustment or was confounded with day.

In conclusion, results indicate that dehydration followed by rehydration does not change average daily water intake, milk production, or $\mathrm{FP}_{\text {milk }}$ in dairy cows under the conditions set in this experiment. Although dehydration followed by increased water intake at rehydration may affect $\mathrm{FP}_{\text {milk }}$ in pastured cows, an increase in $\mathrm{FP}_{\text {milk }}$ above quality limits would not be expected unless the initial $\mathrm{FP}_{\text {milk }}$ is already close to the quality limits during the grazing season. To verify these assumptions, further research seems necessary.

\section{REFERENCES}

Benlamlih, S., and M. Oukessou. 1990. Water movements after an intraruminal water load in pregnant and lactating Sardi sheep. Reprod. Nutr. Dev. 30:227-234.

Bianca, W. 1970. Effects of dehydration, rehydration and overhydration on the blood and urine of oxen. Br. Vet. J. 126:121-132.

Bjerg, M., and M. D. Rasmussen. 2005. Freezing point of bulk tank milk in Denmark. NMC 44th Annual Meeting, Orlando, FL. National Mastitis Council, Verona, WI.

Bligaard, H. B., and K. A. Nielsen. 2004. Afgræsningsundersøgelsen med malkekøer 2003. KvægInfo 1304:1-6. [The grazing study of 2003 involving dairy cows. Danish Cattle Info.] (In Danish).

Cabrera Estrada, J. I., R. Delagarde, P. Faverdin, and J. L. Peyraud. 2004. Dry matter intake and eating rate of grass by dairy cows is restricted by internal, but not external water. Anim. Feed Sci. Technol. 114:59-74.

Castle, M. E., and J. N. Watson. 1973. The intake of drinking water by grazing dairy cows. The effect of water availability. J. Br. Grassl. Soc. 28:203-207.

Choshniak, I., C. Wittenberg, J. Rosenfeld, and A. Shkolnik. 1984. Rapid rehydration and kidney function in the black Bedouin goat. Physiol. Zool. 57:573-579.

Dahlborn, K. 1987. Effect of temporary food or water deprivation on milk secretion and milk composition in the goat. J. Dairy Res. 54:153-163. 
Dahlborn, K., and K. Holtenius. 1990. Fluid absorption from the rumen during rehydration in sheep. Exp. Physiol. 75:45-55.

Dahlborn, K., J. Hossaini-Hilali, and S. Benlamlih. 1997. Changes in fluid balance, milk osmolality and water content during dehydration and rehydration in 2 lactating camels (Camelus dromedarius). J. Camel Pract. Res. 4:207-211.

DeVries, T. J., M. A. G. von Keyserlingk, and K. A. Beauchemin. 2003. Short communication: Diurnal feeding pattern of lactating dairy cows. J. Dairy Sci. 86:4079-4082.

Dewhurst, R. J., N. W. Offer, and C. Thomas. 1998. Factors affecting water intakes of lactating dairy cows offered grass silages differing in fermentation and intake characteristics. Anim. Sci. 66:543-550.

Green, J. E., E. W. Custer, K. R. Cummings, and W. H. McGee. 1969. Effect of a low-energy ration on the freezing point of cow's milk and mammary venous blood serum. J. Dairy Sci. 52:561-562.

Holtenius, K. 1986. Effekter av ett dygns foder- eller vattenbrist på vätskeflödet över våmväggen. Svensk Veterinärtidning 38:714716. [The effect of one day feed or water deprivation on fluid absorption from the rumen.] (In Swedish)

Kleyn, D. H., R. G. Warner, W. F. Shipe, W. K. Jordan, A. C. Dahlberg, and R. F. Davis. 1957. Influence of ration and time of feeding on the freezing point and composition of cow's milk. J. Dairy Sci. 40:1228-1237.

Lee, J. A., J. D. Roussel, and J. F. Beatty. 1976. Effect of temperatureseason on bovine adrenal cortical function, blood cell profile, and milk production. J. Dairy Sci. 59:104-108.

Linzell, J. L., and M. Peaker. 1971a. Permeability of mammary ducts in the lactating goat. J. Physiol. 213:48-49.

Linzell, J. L., and M. Peaker. 1971b. The permeability of mammary ducts. J. Physiol. 216:701-716.

Little, W., B. F. Sansom, R. Manston, and W. M. Allen. 1984. Importance of water for the health and productivity of the dairy cow. Res. Vet. Sci. 37:283-289.

MacFarlane, W. V., and B. Howard. 1966. Water content and turnover of identical twin Bos indicus and B. taurus in Kenya. J. Agric. Sci. 66:297-302.

Maltz, E., N. Silanikove, U. Shalit, and A. Berman. 1994. Diurnal fluctuations in plasma ions and water intake of dairy cows as affected by lactation in warm weather. J. Dairy Sci. 77:2630-2639.

Mitchell, G. E. 1989. The contribution of lactose, chloride, citrate and lactic acid to the freezing point of milk. Aust. J. Dairy Technol. 44:61-64.

Mobasheri, A., and D. Merples. 2004. Expression of the AQP-1 water channel in normal human tissues: A semiquantitative study using tissue microarray technology. Am. J. Physiol. 286:C529-C537.

Peaker, M. 1977. Mechanism of milk secretion: Milk composition in relation to potential difference across the mammary epithelium. J. Physiol. 270:489-505.
Ryan, G. M. 1971. Blood values in cows: Erythrocytes. Res. Vet. Sci. 12:572-575.

SAS Institute. 1999. SAS/STAT User's guide. Software release 8.02. SAS Institute Inc., Cary, NC.

Scott, D. 1975. Changes in mineral, water and acid-base balance associated with feeding and diet. Pages 205-215 in Digestion and metabolism in the ruminant; Proc. IV Int. Symp. Rumin. Physiol. I. W. McDonald and A. C. I. Warner, ed. Armidale, Sydney, Australia. University of New England Publishing Unit, Armidale, Australia.

Shalit, U., E. Maltz, N. Silanikove, and A. Berman. 1991. Water, sodium, potassium, and chlorine metabolism of dairy cows at the onset of lactation in hot weather. J. Dairy Sci. 74:1874-1883.

Shebaita, M. K., and A. Pfau. 1983. Free water intake as a measure of total body water in cattle. Egypt. J. Anim. Prod. 23:119-126.

Shennan, D. B., and M. Peaker. 2000. Transport of milk constituents by the mammary gland. Physiol. Rev. 80:925-951.

Siebert, B. D., and W. V. MacFarlane. 1969. Body water content and water turnover of tropical Bos taurus, Bos indicus, Bibos banteng, and Bos bubalus bubalis. Aust. J. Agric. Res. 20:613-622.

Silanikove, N. 1989. Role of rumen and saliva in the homeostatic response to rehydration in cattle. Am. J. Physiol. 256:R816-R821.

Silanikove, N., and A. Tadmor. 1989. Rumen volume, saliva flow rate, and systemic fluid homeostasis in dehydrated cattle. Am. J. Physiol. 256:R809-R815.

Slaghuis, B. A. 2001. The freezing point of authentic and original farm bulk tank milk in The Netherlands. Int. Dairy J. 11:121-126.

Stockdale, C. R., and K. R. King. 1983. A note on some of the factors that affect the water consumption of lactating dairy cows at pasture. Anim. Prod. 36:303-306.

Tabura, H., K. Ideka, E. Kadota, Y. Murakami, H. Yamada, N. Sasaki, and A. Takeuchi. 1990. Effects of osmolality on water, electrolytes and VFA absorption from the isolated ruminoreticulum in the cow. Jpn. J. Vet. Sci. 52:91-96.

Trinderup, M., and P. S. Enemark. 2003. Besætninger i løsdrift har i gennemsnit den højeste mælkeydelse. KvægInfo 1112:1-9. [Loosed-housed herds have the highest average milk yield. Danish Cattle Info.] (In Danish)

Tucker, V. C. 1970. Effect of nutrition on the freezing point of milk. Aust. J. Dairy Technol. 25:137-139.

Warner, A. C. I., and B. D. Stacy. 1968. The fate of water in the rumen. Br. J. Nutr. 22:389-410.

Warner, A. C. I., and B. D. Stacy. 1972. Water, sodium and potassium movements across the rumen wall of sheep. Q. J. Exp. Physiol. $57: 103-119$.

Wheelock, J. V., J. A. F. Rook, and F. H. Dodd. 1965. The relationship in the cow between the osmotic pressure of milk and of blood. J. Dairy Res. 32:79-88.

Woodford, S. T., M. R. Murphy, and C. L. Davis. 1984. Water dynamics of dairy cattle as affected by initiation of lactation and feed intake. J. Dairy Sci. 67:2336-2343. 